\title{
SOME RECENT PHASES OF THE EVOLUTION OF CASE LAW
}

\author{
Cuthbert W. Pound \\ New York Court of Appeals
}

The law administered in courts of justice may at times not unfairly be styled a system of intellectual knots and puzzles from which may be untangled with some difficulty and delay the rule of action which should have governed the original conduct of the parties to a law suit. Courts which are limited in their review to questions of law exist "not that individual suitors might secure their rights, but that the law should be uniformly settled, to the end that the people might understand the principles which regulated their dealings and conduct." ${ }_{1}$ Law thus laid down for our guidance is neither the rule of right, justice, nor morals although it has a not remote kinship to each. It may be immoral yet legally binding, as conduct may be immoral yet legally unobjectionable. Sound decisions are, however, based on justice, and amid the confused, arbitrary and artificial decisions of indifferent, stupid, hasty, or biased judges handed down from the remote days of the Year Books, stand out fundamental principles of good conduct as elementary as the Ten Commandments and as eternal as Nature. Only as law approximates such a standard does it establish its right to exist, nor would our common law have existed through centuries if it had consistently departed from such a standard.

Justice without law being a helpless thing so far as governmental sanctions go, the lawyer turns to cases, preferably old cases, for a rule of action to apply to a state of facts. Even when he comes to interpret a remedial or clarifying statute, like the Bills of Exchange Act, he roams "over a vast number of authorities in order to discover what the law was, extracting it by a minute critical examination of the prior decisions." 3 The inertia of a judicial decision often carries it along for some distance before the external force of a corrective statute acts upon it. ${ }^{4}$ The lawyer conceives his proper course to be to maintain the law unaltered though the purpose of the statute is frustrated. "Certainty is a matter of quietness and repose, and uncertainty the cause of variance and contentions."

To an outsider like Mr. H. G. Wells who "contemplates the law and

${ }^{2}$ Martin, J., in Reed v. McCord (I899) I60 N. Y. 330, 335, 54 N. E. 737, 738.

'Walter Clark (Chief Justice of the Supreme Court of North Carolina) Some Myths of the Law.

${ }^{3}$ Lord Herschell in Bank of England v. Vagliano [1891, H. L.] A. C. I07, 145.

'Kelso \& Co. v. Ellis (1918) 224 N. Y. 528, 536, I2I N. E. $364,366$. 
lawyers of to-day with a temperamental lack of appreciation,"5 law based on "the traditionary line of decisions" is "a very impracticable and antiquated method indeed." He who becomes involved in it, contrasting its precedents with the rules that govern his business and social world, condemns its jangling formulas as being out of tune with common sense and sound judgment and finds no better basis for its commands than the arrested development of "the customs of our barbarous and semi-barbarous ancestors." Even jurists from whom more understanding and consequently more forbearance might be expected have been known to jeer at their fostering mother.

The power to expound the law often develops in courts and judges a respect for their own mere working theories which confuses a judicial reason for a rule of liability with the laws of nature and the laws of God. Thus Chief-Justice Cullen in Ives v. S. Buffalo Ry. Co., ${ }^{6}$ considering workmen's compensation laws as basically impossible because they impose liability without fault, said:

"I am not impressed with the argument that 'the common law imposed upon the employee entire responsibility for injuries arising out of the necessary risks or dangers of the employment. The statute before us merely shifts such liability upon the employer. ${ }^{\prime 7}$ It is the physical law of nature, not of government, that imposes upon one meeting with an injury, the suffering occasioned thereby. Human law cannot change that. All it can do is to require pecuniary indemnity to the party injured, and I know of no principle on which one can be compelled to indemnify another for loss unless it is based upon contractual obligation or fault. It might as well be argued in support of a law requiring a man to pay his neighbor's debts, that the common law requires each man to pay his own debts, and the statute in question was a mere modification of the common law so as to require each to pay his neighbor's debts."

Such reasoning would have checked the natural development of society if it had been carried to a logical conclusion, but the Court receded from its consequences with good grace after an amendment to the State Constitution which still left the due process clause of the Federal Constitution in the path of the Statute. ${ }^{8}$ It justified itself with a distinction between two statutes resting on no very substantial difference, ${ }^{9}$ and even went the limit and applied the Statute to cases arising out of interstate commerce and in the exclusive admiralty jurisdiction of the United States. ${ }^{10}$

${ }^{5}$ I The Outline of History (1920) 616.

- (I9II) 201 N. Y. 27I, 3I8, 94 N. E. 43I, 449.

'Ives v. S. Buffalo Ry. (I9I0, Sup. Ct.) 68 Misc. 643,646, I24 N. Y. Supp. 920, 923.

${ }^{8}$ Matter of Jensen v. Southern Pacific (I9I5) 2I5 N. Y. 514, Iog N. E. 600.

'Arizona Employers' Liability Cases (I9I9) 250 U. S. 400, 39 Sup. Ct. 553.

${ }^{10}$ Southern Pacific Co. v. Jensen (I915) 2I5 N. Y. 5I4, rog N. E. 600, reversed 
The law courts are of an ancient lineage with too much pride of ancestry to please extreme democratic ideas. The judges often look backward rather than forward. All this is reprehensible and distasteful to advanced thought, intolerant of restraint, yet those who are zealous to give the old dog Law a bad name and bring him into disrepute preparatory to getting rid of the beast entirely should not be heard too credulously. Their motives are not always disinterested nor do they possess the patience with authority that stays rebellion and confusion. Case law is not wholly bound by the rules of past generations. It is a "myth of the law" that stare decisis is impregnable or is anything more than a salutary maxim to promote justice. Although "certainty is the very essence of the law," the law may be changed by the courts by reversing or modifying a rule when the rule has been demonstrated to be erroneous either through failure of adequate presentation of proper consideration, or consideration out of due time of the earlier case, or when "through changed conditions it has become obviously harmful or detrimental to society."11 Speaking of the New York Sales of Goods in Bulk Act, ${ }^{12}$ which was held unconstitutional in 1905, ${ }^{13}$ Judge Cardozo said in 1916: $:^{14}$

"We think it is our duty to hold that the decision in Wright v. Hart is wrong..... The needs of successive generations may make restrictions imperative to-day which were vain and capricious to the vision of times past. Back of this legislation, which to a majority of the judges who decided Wright $v$. Hart seemed arbitrary and purposeless, there must have been a real need. We can see this now, even though it may have been obscure before. Our past decision ought not to stand in opposition to the uniform convictions of the entire judiciary of the land. Least of all should it stand when rendered by a closely divided court against the earnest protest of distinguished judges. . . . The present statute is similar in essentials to the one condemned in 1905. In details it may be distinguished from the earlier one, but the details are in reality trifling. We cannot without a sacrifice of candor rest our judgment upon them. We think we ought not to do so. We should adopt the argument and the conclusion of the dissenting judges in Wright $v$. Hart, and affirm the validity of the statute on which the plaintiff builds his rights."

The unqualified blunt ingenuousness of this opinion is unusual. The Court sometimes reaches the same result as in the Workmen's Compensation Law cases, with more caution and with lip service to the

(Igr7) 244 U. S. 205, 37 Sup. Ct. 524; Knickerbocker Ice Co. v. Stewart (I9I9) 226 N. Y. 302, 123 N. E. 382, reversed (1920) 253 U. S. I49, 40 Sup. Ct. 438.

"See Pollock v. Farmers' Loan \& Trust Co. (1895) I57 U. S. 429, I5 Sup. Ct. 673; Prall v. Burckhartt (I921, Ill.) 132 N. E. 280; Matter of Greifenhagen $v$. Ordway (I9I6) 218 N. Y. 451,458 , II3 N. E. $516,518$.

$\approx$ N. Y. Laws, Ig02, ch. 528.

${ }^{2}$ Wright v. Hart (1905) I82 N. Y. 330,75 N. E. 404.

"Klein v. Maravelas (I9I6) 219 N. Y. 383, 385-386, Ir4 N. E. 809, 810-81r. 
principle of continuity of decisions. In People v. Williams ${ }^{15}$ the Court had, with an air of grave judicial humor, asserted that as woman "has come to possess all the responsibilities of the man, she is entitled to be placed upon an equality of rights with man" and could not be arbitrarily debarred of her right to work in a factory in night hours. In People v. Charles Schweinler Press, ${ }^{16}$ when a like statute came before the Court after the decision of the U. S. Supreme Court in Muller $v$. Oregon, ${ }^{\mathbf{1 7}}$ it was said:

"It is urged that whatever might be our original views concerning this statute, our decision in People v. Williams is an adjudication which ought to bind us to the conclusion that it is unconstitutional. While it may be that this argument is not without an apparent and superficial foundation and ought to be fairly met, I think that a full consideration . of the Williams case and of the present one will show that they may be really and substantially differentiated and that we should not be and are not committed by what was said and decided in the former to the view that the legislature had no power to adopt the present statute."

A rule too bróadly stated may be narrowed by a later decision. The happening of a prior accident at the place where plaintiff fell was held competent proof in sidewalk negligence cases..$^{18}$ But in a later cás $\mathrm{e}^{19}$ it was held that when the plaintiff fell on a hummock of ice caused by a defect in the walk, proof of like accidents two years before was incompetent because the ice was different.

The simulacrum of a rule sometimes appears in a judicial opinion. Its efficacy may be dispelled by distinguishing facts from law, dictum from decision, philosophy from judgment. Thus it has been said with much propriety by the New York Court of Appeals, of claims against decedents' estates, based on a contract for the distribution of the estate, that such claims were dangerous and were regarded with anxiety by the courts which lent an unwilling ear to the statements of what dead men have said; that "the contract should be in writing and the writing produced, or, if ever based upon parol evidence, it should be given or corroborated in all substantial particulars by disinterested witnesses. Unless they are established clearly by satisfactory proofs and are equitable, specific performance should not be decreed." ${ }^{20}$ This language had been adopted by lawyers and judges, not as was designed, as a warning, but as a rule of law and by its application claimants had had their

\footnotetext{
${ }^{15}$ (1907) I89 N.Y. I3I, I37, 8ז N. E. 778, 780.

${ }^{10}$ (I9I5) 214 N. Y. 395, 4I0, I08 N. E. 639, 643.

${ }^{17}$ (1908) 208 U. S. 412, 28 Sup. Ct. 324.

${ }^{18}$ Quinlan v. City of Utica (I877, Sup. Ct.) II Hun, 2I7, affirmed (I878) 74 N. Y. 603.

${ }^{29}$ Gillrie v. City of Lockport (I890) I22 N. Y. 403, 25 N. E. 357.

${ }^{20}$ Hamlin v. Stevens (1903) I77 N. Y. 39, 50, 69 N. E. II8, I21 ; Rosseau v. Rouss (1904) I80 N. Y. II6, 72 N. E. 9I6; Tousey v. Hastings (1909) I94 N. Y. 79, 86 N. E. 83 I.
} 
rights taken from them although the trial court believed, and declared its belief that their witnesses told the exact truth, because their evidence was not thus standardized. The Court of Appeals set the trial courts right in McKeon $v$. VanSlyk.1 It distinguished between a real rule that the plaintiff in a civil case is never required to prove his case by more than a preponderance of evidence and the simulacrum of a rule that is in substance nothing more than a counsel of caution which the trier of fact should heed when he weighs the evidence in an action against an executor founded on a claim put forward for the first time after the death of a testator..$^{22}$

The stability of legal decisions is often more theoretical than substantial. In Lazerence $v . F_{0} x^{23}$ the rule was broadly stated, under the mistaken notion that it was the settled law of England, "that where one person makes a promise to another for the benefit of a third person, that third person may maintain an action upon it," but at the earliest opportunity the donee beneficiary was put out of court and it was held that the third party could sue on the contract only where "there has been a debt or duty owing by the promisee to the party claiming to sue upon the promise. ${ }^{24}$ At the present time, turning again to Lawrence $v$. Fox, it would seem the donee beneficiary as well as the obligee beneficiary has at least a fighting chance to re-establish the earlier and more convenient if less logical rule in its entirety. ${ }^{25}$

Again, looking at a well considered dictum, it seems to have been held in Corbett v. St. Vincent's School ${ }^{26}$ that the agents of the state, doing the state's work, share the state's immunity from liability for their torts. The recent case of Murtha v. N.Y. Homeopathic, etc. Hospital ${ }^{27}$ states the correct rule that "agents and contractors, though unable to impose liability in such circumstances on the state or its divisions, remain liable themselves and this whether they act in person or by sub-agents or servants . . . . Much that was said in the opinion" (in the Corbett case), says the Court, "was unnecessary to the decision."

It would be futile to multiply instances to demonstrate the principle that case law is not wholly a matter of precedent; that much has been said in deciding cases that is not essentially law; that case law, in a qualified way at least, is a progressive science; that legal doctrines deemed revolutionary a century ago are listened to respectfully to-day; that the opportunity still exists for great lawyers to make great argu-

${ }^{2}$ (1918) 223 N. Y. 392, 397, Iт9 N. E. 851, 852.

See Matter of Sherman (19I9) 227 N. Y. 350 , I25 N. E. 546.

${ }^{23}$ (1859) 20 N. Y. 268.

"Vrooman v. Turner (I877) 69 N. Y. 280.

${ }^{25}$ Seaver v. Ransom (I9I7) I80 App. Div. 734, I68 N. Y. Supp. 454, affirmed (I9I8) 224 N. Y. 233, I20 N. E. 639.

${ }^{28}$ (1903) I77 N. Y. 16, 68 N. E. 997.

${ }^{27}$ (1920) 228 N. Y. 183, I85, I26 N. E. 722. 
ments in the face of obsolescent decisions and for judges not only to "hold fast to that which is good," as they must in all decency and respect for their place, but "to prove,-i. e. establish the validity of,all things." 28

Hard cases make bad law. A judge must have undue regard for his own conclusions lightly to make distinctions in order to qualify authority with his personal notions of right and wrong. On the other hand the pursuit of justice in judicial decisions is not a joke. "What is truth?' said jesting Pilate, and paused not for a reply." Fiat justicia, but what is justice? Steadily adhered to principles, or some man's idea of what would be just and fair for the parties considering their relative sex, wealth, good fortune and the like? The former, doubtless as a rule are the better guide, but a decision does not, merely because it is old, fetter the courts forever.

${ }^{28}$ Holy Bible, I Thessalonians 5 : 2r. 